\title{
CRIMINAL DATA MANAGEMENT - RELEVANT SOURCES OF EU LAW, INTEROPERABILITY OF EU INFORMATION SYSTEMS
}

\author{
ANDREA JÁNOSI*
}

\begin{abstract}
Interoperability of information systems on Justice and Home Affairs is not just a vision anymore. In 2019 two regulations were adopted in order to create the legal framework of interoperability. The purpose of this study is to present how the idea and concept of interoperability of JHA information systems appeared in different EU legal documents as an objective and to give an overview about the core elements of the current interoperability framework.
\end{abstract}

Keywords: interoperability, Justice and Home Affairs, information systems, interoperability components

\section{FOREWORD}

Interoperability is an often mentioned term in the EU policies. However, the concept of interoperability is not clear or generally defined, it is referred to in several legal documents as an objective to be achieved. According to some approaches, "interoperability can be tentatively described as the ability of an information system to exchange data and enable information-sharing with a technically different information system and to use the information that has been exchanged". ${ }^{1}$ Other studies pointed out the fundamental rights' aspect of interoperability. ${ }^{2}$ For example "interoperability will enhance the cooperation and efficiency between migration agencies, police forces and judicial bodies," but "without the right safeguards, it could become a dangerous tool against fundamental rights. ",3

The main purpose of this article is to demonstrate how the idea of interoperability of information systems appears in the legislation of the EU related to police

* Assistant professor, University of Miskolc, Faculty of Law, Institute of Criminal Sciences, Department of Criminal Procedural Law and Criminal Enforcement.

1 GALLI, Francesca: Interoperable Law Enforcement Cooperation Challenges in the EU Area of Freedom, Security and Justice. EUI Working Papers, European University Institute, Robert Schuman Centre for Advanced Studies, 2019, p. 2.

2 CARrera, Sergio - STEFAn, Marco - Cortinovis, Roberto - LuK, Ngo Chun: When mobility is not a choice. Problematising asylum seekers' secondary movements and their criminalisation in the EU. CEPS Paper, 2019, p. 16.

https://www.ceps.eu/wp-content/uploads/2019/12/LSE2019-11-RESOMA-Policing-secondary-movements-in-the-EU.pdf, 20. 8. 2021.

3 Blasi CASAgRAN, Cristina: Fundamental Rights Implications of Interconnecting Migration and Policing Databases in the EU. Human Rights Law Review, Volume 21, Issue 2, June 2021, p. 434. 
and judicial cooperation and to highlight the core elements of the current interoperability framework.

\section{LEGAL BACKGROUND OF INTEROPERABILITY ${ }^{4}$}

From 2005 the issue of interoperability of Justice and Home Affairs Information Systems was raised more frequently in the policies of the EU and this objective has also appeared in several EU legal documents. For example in the same year the Commission adopted a Communication on improved effectiveness, enhanced interoperability and synergies among European databases in the area of Justice and Home Affairs. ${ }^{5}$ This document aimed to demonstrate how the currently operating information systems - such as: the second generation Schengen Information System (SIS II) ${ }^{6}$ Visa Information System (VIS) ${ }^{7}$ and Eurodac ${ }^{8}$ - would be able to more effectively

4 This chapter is mainly based on the following article: JÁNOSI, Andrea: The need for interoperability between EU information systems in the area of police and judical cooperation in criminal matters. Ügyészségi Szemle, 2020/3, pp. 61-81.

5 Communication from the Commission to the Council and the European Parliament on improved effectiveness, enhanced interoperability and synergies among European databases in the area of Justice and Home Affairs. COM/2005/0597 final. Hereinafter referred to as: COM/2005/0597 final.

6 Regulation (EC) No 1987/2006 of the European Parliament and of the Council of 20th December 2006 on the establishment, operation and use of the second generation Schengen Information System (SIS II). OJ L 381, 28. 12. 2006, pp. 4-23.

Council Decision 2007/533/JHA of 12th June 2007 on the establishment, operation and use of the second generation Schengen Information System (SIS II). OJ L 205, 7. 8. 2007, pp. 63-84.

Regulation (EC) No 1986/2006 of the European Parliament and of the Council of 20th December 2006 regarding access to the Second Generation Schengen Information System (SIS II) by the services in the Member States responsible for issuing vehicle registration certificates. OJ L 381, 28. 12. 2006, pp. 1-3.

2010/261/: Commission Decision of 4th May 2010 on the Security Plan for Central SIS II and the Communication Infrastructure. OJ L 112, 5. 5. 2010, pp. 31-37.

7 Regulation (EC) No 767/2008 of the European Parliament and of the Council of 9th July 2008 concerning the Visa Information System (VIS) and the exchange of data between Member States on short-stay visas (VIS Regulation). OJ L 218, 13. 8. 2008, pp. 60-81 (Hereinafter referred to as: VIS Regulation).

8 Regulation (EU) No 603/2013 of the European Parliament and of the Council of 26th June 2013 on the establishment of 'Eurodac' for the comparison of fingerprints for the effective application of Regulation (EU) No 604/2013 establishing the criteria and mechanisms for determining the Member State responsible for examining an application for international protection lodged in one of the Member States by a third-country national or a stateless person and on requests for the comparison with Eurodac data by Member States' law enforcement authorities and Europol for law enforcement purposes, and amending Regulation (EU) No 1077/2011 establishing a European Agency for the operational management of large-scale IT systems in the area of freedom, security and justice. OJ L 180, 29. 6. 2013, pp. 1-30 (Hereinafter referred to as: Eurodac Regulation). 
support the policies linked to free movement of persons and to combat against terrorism and serious crime, drew attention to the weaknesses of the current information systems and made suggestions for the solution. ${ }^{9}$ This paper contained the notion of interoperability in a slightly debatably way, which was also criticised by the related comments of the European Data Protection Supervisor. ${ }^{10}$

Till the publication of the proposals of the interoperability regulations, the significance of interoperability was also highlighted in the following events and documents:

- Conclusions of the Council of the EU and of the Member States meeting within the Council on Counter-Terrorism ${ }^{11}$

- Conclusions of the European Council meeting of 17th and 18th December $2015^{12}$

- Joint statement of EU Ministers for Justice and Home Affairs and representatives of EU institutions on the terrorist attacks in Brussels on 22nd March $2016^{13}$

- Communication: Stronger and smarter information systems for borders and security $^{14}$

- Roadmap to enhance information exchange and information management including interoperability solutions in the Justice and Home Affairs area ${ }^{15}$

- Commission decision on setting up the High Level Expert Group on Information Systems and Interoperability ${ }^{16}$

- Conclusions of the European Council meeting on 15th December $2016^{17}$

$9 \mathrm{COM} / 2005 / 0597$ final.

10 European Data Protection Supervisor: Comments on the Communication of the Commission on interoperability of European databases Brussels, 10th March 2006. https://edps. europa.eu/sites/edp/files/publication/06-03-10_interoperability_en.pdf, 11. 7. 2021.

11 Conclusions of the Council of the EU and of the Member States meeting within the Council on Counter-Terrorism (20th November 2015). https://www.consilium.europa.eu/en/ press/press-releases/2015/11/20/jha-conclusions-counter-terrorism/, 11. 7. 2021.

12 European Council meeting (17th and 18th December 2015) - Conclusions. EUCO 28/15. https://www.consilium.europa.eu/media/21669/201512-euco-conclusions.pdf, 11. 7. 2021.

13 Joint statement of EU Ministers for Justice and Home Affairs and representatives of EU institutions on the terrorist attacks in Brussels on 22nd March 2016 (24th March 2016). https://www.consilium.europa.eu/en/press/press-releases/2016/03/24/statement-on-terrorist attacks-in-brussels-on-22-march/, 11. 7. 2021.

14 Communication from the Commission to the European Parliament and the Council Stronger and Smarter Information Systems for Borders and Security. COM/2016/0205 final.

15 Roadmap to enhance information exchange and information management including interoperability solutions in the Justice and Home Affairs area. Brussels, 9368/1/16, 6th June 2016. http://data.consilium.europa.eu/doc/document/ST-9368-2016-REV-1/en/pdf, 11. 7. 2021.

16 Commission Decision of 17th June 2016 setting up the High Level Expert Group on Information Systems and Interoperability. OJ C 257, 15. 7. 2016, pp. 3-6. Articles 2-3.

17 European Council meeting (15th December 2016) - Conclusions. Brussels, EUCO 34/16, 15th December 2016. https://www.consilium.europa.eu/media/21929/15-euco-conclusionsfinal.pdf, 11. 7. 2021. 
- Communication from the Commission - Seventh progress report towards an effective and genuine Security Union ${ }^{18}$

- High-level expert group on information systems and interoperability. Final Report. ${ }^{19}$

- Conclusions of the European Council meeting on 22nd and 23rd June $2017^{20}$

Their common message was that enforcement cooperation should be more enhanced by improving information sharing and data exchange and interoperability would be a key tool for this.

On 12th December 2017, the Commission adopted two proposals for interoperability. The first proposal was for a regulation on establishing a framework for interoperability between EU information systems on borders and visa, ${ }^{21}$ the second for a regulation on interoperability in the area of police and judicial cooperation, asylum and migration. ${ }^{22}$ These proposals were followed by a number of critical remarks. These comments were included in the opinion of the European Data Protection Supervisor $^{23}$, the European Union Agency for Fundamental Rights (FRA) ${ }^{24}$, and the

18 Communication from the Commission to the European Parliament, the European Council and the Council Seventh progress report towards an effective and genuine Security Union. COM/2017/0261 final.

19 High-level expert group on information systems and interoperability. Final Report. May 2017. https://ec.europa.eu/transparency/regexpert/index.cfm?do=groupDetail.groupDetailDoc\&id $=32600 \&$ no $=1,11.7 .2021$.

20 European Council meeting (22nd and 23rd June 2017) - Conclusions. EUCO 8/17. Brussels, 23rd June 2017. https://www.consilium.europa.eu/media/23985/22-23-euco-finalconclusions.pdf, 11. 7. 2021.

21 Proposal for a regulation of the European Parliament and of the Council on establishing a framework for interoperability between EU information systems (borders and visa) and amending Council Decision 2004/512/EC, Regulation (EC) No 767/2008, Council Decision 2008/633/JHA, Regulation (EU) 2016/399 and Regulation (EU) 2017/2226. COM/2017/0793 final - 2017/0351 (COD).

22 Proposal for a regulation of the European Parliament and of the Council on establishing a framework for interoperability between EU information systems (police and judicial cooperation, asylum and migration). COM/2017/0794 final - 2017/0352 (COD).

23 EDPS Opinion 4/2018 on the Proposals for two Regulations establishing a framework for interoperability between EU large-scale information systems. 16th April 2018. https://edps.europa.eu/sites/edp/files/publication/2018-04-16_interoperability_opinion_en. pdf, 11. 7. 2021.

Press release. EDPS/2018/04. EDPS calls for wider debate on the future of information sharing in the EU. https://edps.europa.eu/sites/edp/files/edpsweb_press_releases/edps2018-04-interoperability_en.pdf, 11.7.2021.

WAHL, Thomas: EDPS Further Critical to Interoperability. Eucrim, 1/2018, p. 20.

https://eucrim.eu/news/edps-further-critical-interoperability/, 11. 7. 2021.

24 Interoperability and fundamental rights implications. Opinion of the European Union Agency for Fundamental Rights. Vienna, 11th April 2018.

RIEHLE, Cornelia: FRA Opinion on Interoperability. Eucrim, 1/2018, p. 21. https://eucrim.eu/news/fra-opinion-interoperability/, 11. 7. 2021. 
Article 29 Data Protection Working Party (WP29) ${ }^{25}$. On 13th June 2018, the European Commission published two amending proposals. ${ }^{26}$ After several debates, technical changes and corrections, the regulations ${ }^{27}$ were finally adopted on 20th May 2019.

\section{THE CONCEPTION OF INTEROPERABILITY AND THE STRUCTURE OF THE INTEROPERABILITY FRAMEWORK}

\subsection{The scope of the interoperability framework - the related information systems}

The common aim of these above mentioned interoperability regulations is to establish a framework to ensure interoperability between VIS, SIS, Eurodac and another

25 WAHL, Thomas: Data Protection Experts Give Critical Statement on Planned Interoperability. Eucrim, 1/2018, p. 21. https://eucrim.eu/news/data-protection-experts-give-critical-statement-planned-interoperability/, 11. 7. 2021.

Article 29 Data Protection Working Party. Opinion on Commission proposals on establishing a framework for interoperability between EU information systems in the field of borders and visa as well as police and judicial cooperation, asylum and migration. Adopted on 11th April 2018. IV. Conclusion. pp. 20-22. https://ec.europa.eu/newsroom /article29/item-detail.cfm?item_id=624198, 11. 7. 2021.

26 Amended proposal for a regulation of the European Parliament and of the Council on establishing a framework for interoperability between EU information systems (borders and visa) and amending Council Decision 2004/512/EC, Regulation (EC) No 767/2008, Council Decision 2008/633/JHA, Regulation (EU) 2016/399, Regulation (EU) 2017/2226, Regulation (EU) 2018/XX [the ETIAS Regulation], Regulation (EU) 2018/XX [the Regulation on SIS in the field of border checks] and Regulation (EU) 2018/XX [the eu-LISA Regulation]. COM/2018/478 final.

Amended proposal for a regulation of the European Parliament and of the Council on establishing a framework for interoperability between EU information systems (police and judicial cooperation, asylum and migration) and amending [Regulation (EU) 2018/XX [the Eurodac Regulation],] Regulation (EU) 2018/XX [the Regulation on SIS in the field of law enforcement], Regulation (EU) 2018/XX [the ECRIS-TCN Regulation] and Regulation (EU) 2018/XX [the eu-LISA Regulation]. COM/2018/480 final.

27 Regulation (EU) 2019/817 of the European Parliament and of the Council of 20th May 2019 on establishing a framework for interoperability between EU information systems in the field of borders and visa and amending Regulations (EC) No 767/2008, (EU) 2016/399, (EU) 2017/2226, (EU) 2018/1240, (EU) 2018/1726 and (EU) 2018/1861 of the European Parliament and of the Council and Council Decisions 2004/512/EC and 2008/633/JHA. OJ L 135, 22.05.2019, pp. 27-84 (Hereinafter referred to as: 2019a)

Regulation (EU) 2019/818 of the European Parliament and of the Council of 20th May 2019 on establishing a framework for interoperability between EU information systems in the field of police and judicial cooperation, asylum and migration and amending Regulations (EU) 2018/1726, (EU) 2018/1862 and (EU) 2019/816. OJ L 135, 22. 5. 2019, pp. 85-135 (Hereinafter referred to as: 2019b).

WAHL, Thomas: Works on Interoperability of EU Information Systems Can Start - Legal Framework Established. Eucrim, 2/2019, pp. 103-104. https://eucrim.eu/news/works-oninteroperability-of-eu-information-systems-can-start/, 11. 7.2021. 
three centralised information systems, which are under development, such as: (1) EES $^{28}$, (2) ETIAS ${ }^{29}$ and (3) ECRIS-TCN ${ }^{30}$. Moreover, this structure should also cover Europol data to some extent [2019a and 2019b Preamble (11)].

A) VIS:

On 8th June 2004 the Council of the European Union adopted a decision establishing the Visa Information System. ${ }^{31}$ It has been operational since 2011. The hereby established VIS should enable authorised national authorities to enter and update visa data and to consult these data electronically (VIS Decision Art. 1). VIS therefore serves to ensure the exchange of visa data between Member States in order to facilitate the implementation of the common visa policy, consular cooperation and consultation between central visa authorities. The latter will facilitate the visa application process, the fight against fraud, checks at external border crossing points and on the territory of the Member States prevent "visa shopping" and assist in identification of persons who may not or no longer fulfil the conditions for entry, to stay or to residence on the territory of the Member States and to contribute to the prevention of threats to the internal security of the Member States (VIS Regulation Art. 2 and (5) Preamble).

B) SIS

SIS is a large-scale IT system that is an essential tool for maintaining public security and public order in the Schengen Area. It was established on the basis of the Convention Implementing the Schengen Agreement. ${ }^{32}$ The second generation of SIS

28 Regulation (EU) 2017/2226 of the European Parliament and of the Council of 30th November 2017 establishing an Entry/Exit System (EES) to register entry and exit data and refusal of entry data of third-country nationals crossing the external borders of the Member States and determining the conditions for access to the EES for law enforcement purposes, and amending the Convention implementing the Schengen Agreement and Regulations (EC) No 767/2008 and (EU) No 1077/2011. OJ L 327, 9. 12. 2017, pp. 20-82. (Hereinafter referred to as: EES Regulation).

29 Regulation (EU) 2018/1240 of the European Parliament and of the Council of 12th September 2018 establishing a European Travel Information and Authorisation System (ETIAS) and amending Regulations (EU) No 1077/2011, (EU) No 515/2014, (EU) 2016/399, (EU) 2016/1624 and (EU) 2017/2226. OJ L 236, 19.09.2018, pp. 1-71 (Hereinafter referred to as: ETIAS Regulation).

30 Regulation (EU) 2019/816 of the European Parliament and of the Council of 17th April 2019 establishing a centralised system for the identification of Member States holding conviction information on third-country nationals and stateless persons (ECRIS-TCN) to supplement the European Criminal Records Information System and amending Regulation (EU) 2018/1726. OJ L 135, 22. 5. 2019, pp. 1-26 (Hereinafter referred to as: ECRISTCN Regulation).

31 2004/512/EC: Council Decision of 8th June 2004 establishing the Visa Information System (VIS) OJ L 213, 15. 6. 2004, pp. 5-7 (Hereinafter referred to as: VIS Decision).

32 Convention implementing the Schengen Agreement of $14^{\text {th }}$ June 1985 between the Governments of the States of the Benelux Economic Union, the Federal Republic of Germany and the French Republic on the gradual abolition of checks at their common borders. 
(SIS II), which replaced SIS I, became operational on 9th April 2013. In December 2018 three new regulations on the system were published in the Official Journal of the European Union: (1) on the use of the Schengen Information System for the return of illegally staying third-country nationals; (2) on the establishment, operation and use of SIS in the field of border checks; (3) on the establishment, operation and use of SIS in the field of police cooperation and judicial cooperation in criminal matters. ${ }^{33}$ This reform package introduced a number of technical and operational improvements to the functioning of the system.

\section{C) Eurodac}

The Eurodac system, which has been operational since 2003, is the central computerized database for fingerprint data established by Council Regulation (EC) No $2725 / 2000 .^{34}$ The system was reformed in 2013 with the aim of making it more efficient and regulating the conditions for access for law enforcement purposes. The main purpose of this system is to assist in determining which Member State is to be responsible for examining an application for international protection lodged by a third-country national or a stateless person. It facilitates the identification of applicants for international protection and persons apprehended in connection with the unlawful crossing of the external borders of the Union and verifies whether a thirdcountry national or a stateless person staying illegally in the territory of a Member State has previously applied for international protection in another Member State [Eurodac Regulation Art. 1(1) and (4) Preamble].

\section{D) EES (Entry/Exit System)}

The regulation establishing an Entry/Exit System (EES) to register entry and exit data and refusal of entry data of third-country nationals crossing the external borders of the Member States and determining the conditions for access to the EES for law

33 Regulation (EU) 2018/1860 of the European Parliament and of the Council of 28 th November 2018 on the use of the Schengen Information System for the return of illegally staying third-country nationals. OJ L 312, 7. 12. 2018, pp. 1-13.

Regulation (EU) 2018/1861 of the European Parliament and of the Council of 28 November 2018 on the establishment, operation and use of the Schengen Information System (SIS) in the field of border checks, and amending the Convention implementing the Schengen Agreement, and amending and repealing Regulation (EC) No 1987/2006. OJ L 312, 7. 12. 2018, pp. 14-55.

Regulation (EU) 2018/1862 of the European Parliament and of the Council of 28th November 2018 on the establishment, operation and use of the Schengen Information System (SIS) in the field of police cooperation and judicial cooperation in criminal matters, amending and repealing Council Decision 2007/533/JHA, and repealing Regulation (EC) No 1986/2006 of the European Parliament and of the Council and Commission Decision 2010/261/EU OJ L 312, 7. 12. 2018, pp. 56-106.

34 Council Regulation (EC) No 2725/2000 of 11 th December 2000 concerning the establishment of 'Eurodac' for the comparison of fingerprints for the effective application of the Dublin Convention. OJ L 316, 15. 12. 2000, pp. 1-10 (Not in force). 
enforcement purposes was adopted in 2017. The EES applies to third-country nationals entitled to enter the territory of the Member States for short stays and to thirdcountry nationals whose entry for a short stay has been refused. [EES Regulation Preamble (9) and Art. 2] The tasks of the system are: (1) the recording and storage of the date, time and place of entry and exit of third-country nationals crossing the borders of the Member States at which the EES is operated; (2) the calculation of the duration of the authorised stay of such third-country nationals; (3) the generation of alerts to Member States when the authorised stay has expired; (4) the recording and storage of the date, time and place of refusal of entry of third-country nationals, the authority of the Member State which refused the entry and the reasons therefor. (EES Regulation Art. 1)

E) European Travel Information and Authorisation System (ETIAS)

ETIAS, also primarily for border management purposes, is expected to become operational in 2022. The need to set this system up was already reflected in the Commission's Communication in $2016 .{ }^{35}$ It will be responsible for issuing, on the basis of the information stored in or uploaded to it, a fee-based travel authorization - a decision - which will be a new condition for entry into the territory of the Member States. The system makes it possible to examine whether the presence of the persons concerned in the territory of the Member States poses any risk of security, illegal immigration or a high level of epidemiology, or whether it will pose such a risk in the future. This system should apply to third-country nationals who are exempt from the visa requirement (ETIAS Regulation Art. 1).

\section{F) ECRIS-TCN}

The purpose of setting up the system of ECRIS-TCN was essentially to enable decisions taken in each Member State on third-country nationals to be taken into account in other Member States in new criminal proceedings and in order to prevent the commission of new criminal offenses. It should be noted that the original ECRIS system, set up under Council Framework Decision 2009/315/JHA to ensure the exchange of judgments between Member States, has been operational since 2012 and has so far allowed Member States to exchange information on third-country nationals. However, this function was not effective enough [ECRIS-TCN Regulation Preamble (2)(5)]. The ECRIS-TCN regulation should apply to third-country nationals and stateless persons, as well as citizens of the Union who also hold the nationality of a third country (Art. 2).

35 Proposal for a Regulation of the European Parliament and of the Council establishing a European Travel Information and Authorisation System (ETIAS) and amending Regulations (EU) No 515/2014, (EU) 2016/399, (EU) 2016/794 and (EU) 2016/1624. COM/2016/0731 final. 


\subsection{The components of the present interoperability framework}

According to the regulations (2019a and 2019b Art. 2) interoperability would ensure the following objectives:

"(a) to improve the effectiveness and efficiency of border checks at external borders;

(b) to contribute to the prevention and the combating of illegal immigration;

(c) to contribute to a high level of security within the area of freedom, security and justice of the Union including the maintenance of public security and public policy and safeguarding security in the territories of the Member States;

(d) to improve the implementation of the common visa policy;

(e) to assist in the examination of applications for international protection;

(f) to contribute to the prevention, detection and investigation of terrorist offences and of other serious criminal offences;

(g) to facilitate the identification of unknown persons who are unable to identify themselves or unidentified human remains in case of a natural disaster, accident or terrorist attack."

In order to achieve these objectives, this framework would include the following four interoperability components: (1) European search portal (ESP); (2) shared biometric matching service (shared BMS); (3) common identity repository (CIR); and (4) multiple-identity detector (MID).

1. ESP enables the simultaneous querying of the EES, VIS, ETIAS, Eurodac, SIS, ECRIS-TCN, Europol data and the Interpol databases for the competent authorities (such as: EU agencies and authorities of the Member States) [2019a and 2019b Art. 6(1)]. Only Member State authorities and EU agencies with access to at least one EU information system may use the ESP [2019a and 2019b Art. 7(1)]. The queries are based on the submitting alphanumeric or biometric data to the ESP [2019a and 2019b Art. 9(1)]. EES, ETIAS, VIS, SIS, Eurodac, ECRIS-TCN, CIR and MID, as well as Europol data and Interpol databases, make the data they store available in response to a query [2019a and 2019b Art. 9(4)].

2. A shared biometric matching service (shared BMS) stores biometric templates and makes it possible to query several EU information systems with biometric data [2019a and 2019b Art. 12(1)]. It will also include in each biometric template a reference to the EU information systems in which the corresponding biometric data are stored [2019a and 2019b Art. 13(2)].

3. A common identity repository (CIR) will create an individual file for each person that is registered in the EES, VIS, ETIAS, Eurodac or ECRIS-TCN [2019a and 2019b Art. 17(1)]. It manages the following data: surname, first name(s), date of birth, place of birth, nationality or nationalities, gender, previous names, pseudonyms or aliases, information on travel documents. In addition, CIR will also include a reference to the EU information systems to which the above mentioned data belong [2019a and 2019b Art. 18(1)-(2)]. CIR can be accessed for different purposes: (1) access for identification; (2) 
access for the detection of multiple identities; (3) querying for the purposes of preventing, detecting or investigating terrorist offences or other serious criminal offences.

4. The multiple-identity detector (MID) allows detection of multiple identities. It supports the functioning of the CIR and the objectives of the EES, VIS, ETIAS, Eurodac, SIS and ECRIS-TCN [2019a and 2019b Art. 25(1)]. In order to achieve this goal, MID will create and store links between data in the different EU information systems. It contains links between data on individuals, who are present in more than one EU information system [2019a and 2019b Preamble (39)].

In addition to the interoperability components, these regulations contain detailed rules regarding measures supporting interoperability, these are: the data quality, the universal message format (UMF) and the central repository for reporting and statistics (CRRS) (2019a and 2019b Art. 37-39). The universal message format (UMF) would be a standard for structured, cross-border information exchange in the field of JHA [2019a and 2019b Preamble (50)]. Moreover, these regulations include detailed rules on data protection (such as: rules related to data controller, data processor, security of processing, security incidents, self-monitoring, right to information, web portal, etc.) as well.

The regulations laid down how the responsibilities are to be shared between EU institutions and Member States. According to the regulations, eu-LISA should ensure the operation of the central infrastructures of the interoperability components and it is also responsible for the technical management of the central infrastructure, including the maintenance and technological developments of the elements. Member States are responsible for example for the connection to the communication infrastructure of the ESP and the CIR, the organisation, management, operation and maintenance of its existing national infrastructure and of its connection to the interoperability components, the compliance with the data quality requirements established under Union law and the rules of each EU information system regarding the security and integrity of personal data, etc. (2019a and 2019b Art. 56). Europol inter alia ensures the handling of queries for Europol data via the ESP (2019b Art. 57). The ETIAS Central Unit is responsible for the manual verification of different identities and carrying out multiple-identity detection between the data stored in the EES, VIS, Eurodac and SIS (2019a Art. 57 and 2019b Art. 58).

\section{Closing ReMARKS}

It is well seen, that interoperability of information systems on Justice and Home Affairs as an objective has already appeared in several EU legal documents. The need to create this framework constantly arose and became more and more justified. After the adoption of the two examined regulations, this system is not just a vision anymore. It is undeniable that its operation raises a number of fundamental rights issues, 
although these issues were not the subject of the present study. The technical elements of the interoperability framework are under development; it is supposed to be operational by $2023 .^{36}$ There is no doubt, that these regulations create the quite complex system of collecting and storing data and their practical application will obviously raise several questions. Hopefully, this framework will be an effective tool for improving information management and data exchange between the national authorities on EU level.

\section{LIST OF LITERATURE}

[1] Blasi CASAgRan, Cristina: Fundamental Rights Implications of Interconnecting Migration and Policing Databases in the EU. Human Rights Law Review, Volume 21, Issue 2, June 2021. https://doi.org/10.1093/hrlr/ngaa057

[2] CARRERA, Sergio - Stefan, Marco - Cortinovis, Roberto - LuK, Ngo Chun: When mobility is not a choice. Problematising asylum seekers' secondary movements and their criminalisation in the EU. CEPS Paper, 2019. https://www.ceps.eu/wp-content/uploads/2019/12/LSE2019-11-RESOMAPolicing-secondary-movements-in-the-EU.pdf, 20. 8. 2021.

[3] GALLI, Francesca: Interoperable Law Enforcement Cooperation Challenges in the EU Area of Freedom, Security and Justice. EUI Working Papers, European University Institute, Robert Schuman Centre for Advanced Studies, 2019.

[4] JÁNOSI, Andrea: The need for interoperability between EU information systems in the area of police and judical cooperation in criminal matters. $\ddot{U} g y$ észségi Szemle, 2020/3, pp. 61-81.

[5] RIEHLE, Cornelia: FRA Opinion on Interoperability. Eucrim, 1/2018, p. 21. https://eucrim.eu/news/fra-opinion-interoperability/, 11. 7. 2021.

[6] WAHL, Thomas: EDPS Further Critical to Interoperability. Eucrim, 1/2018. https://eucrim.eu/news/edps-further-critical-interoperability/, 11. 7. 2021.

[7] WAHL, Thomas: Data Protection Experts Give Critical Statement on Planned Interoperability. Eucrim, 1/2018.

https://eucrim.eu/news/data-protection-experts-give-critical-statement-planned -interoperability/, 11. 7. 2021.

[8] WAHL, Thomas: Works on Interoperability of EU Information Systems Can Start - Legal Framework Established. Eucrim, 2/2019.

https://eucrim.eu/news/works-on-interoperability-of-eu-information-systemscan-start/, 11. 7. 2021.

36 BLASI CASAgRAN: op. cit. p. 441. 